\title{
LABELS: Laboratoř behaviorálních a lingvistických studií
}

\author{
Filip Děchtěrenko
}

Laboratoř behaviorálních a lingvistických studií je společným pracovištěm Psychologického ústavu Akademie věd ČR v.v.i. a Filozofické fakulty Univerzity Karlovy. V současné době se naše laboratoř zabývá zejména vizuální psychologií, osvojováním jazyka a řeči u dětí, zpracováním jazyka u dospělých a obecně kognicí u dětí a dospělých, nicméně je otevřená i dalším typům projektů. Kromě využití běžného sběru dat pomocí počítačů využíváme také zařízení pro sledování očních pohybů (eye-tracker), měření elektrické aktivity mozku (EEG) či dalších fyziologických měření (Obr. 1-3). Plánujeme také využití funkční infračervené spektroskopie (fNIRS). Experimentů v laboratoři se ročně účastí stovky studentů, primárně z Filozofické fakulty. Vedoucím laboratoře je Filip Smolík, který se zabývá výzkumem jazyka jak u dospělých, tak dětí. $Z$ dalších aktivních výzkumníků můžeme zmínit Kateřinu Chládkovou, která se zaměřuje na vnímání řeči u kojenců, či Jiřího Lukavského a Filipa Děchtěrenka studující vizuální pamět' a pozornost. Dále spolupracujeme s dalšími výzkumníky z Matematicko-fyzikální fakulty Univerzity Karlovy (MFF UK), Př́rodovědecké fakulty či Pedagogické fakulty UK $\mathrm{v}$ mnoha dalších společných projektech zabývající se psycholingvistikou (Jan Chromý, Filozofická fakulta UK) či třeba výukovými simulacemi (Cyril Brom, MFF UK).

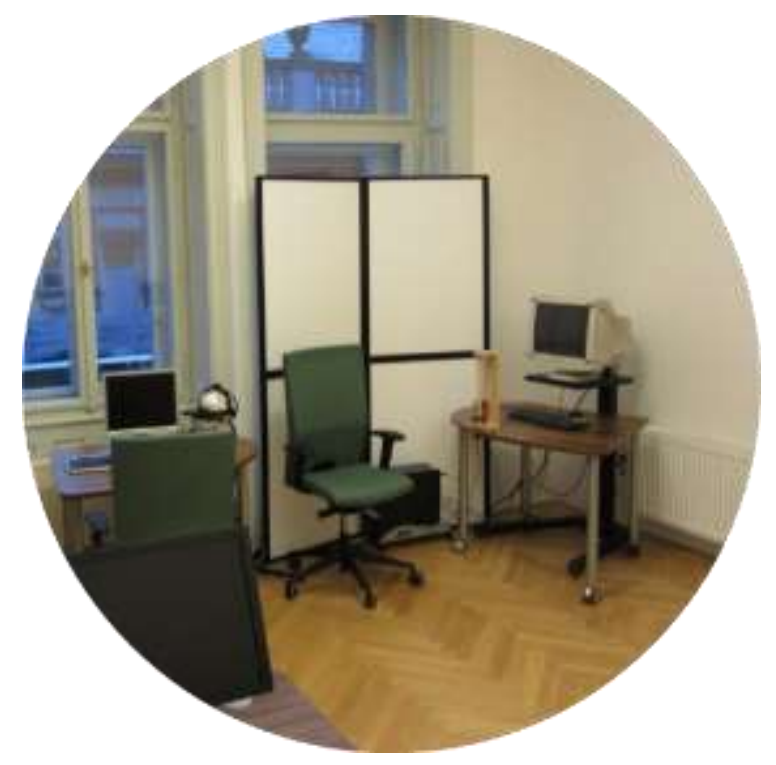

Obr. 1. Ukázka přístrojového vybavení. 

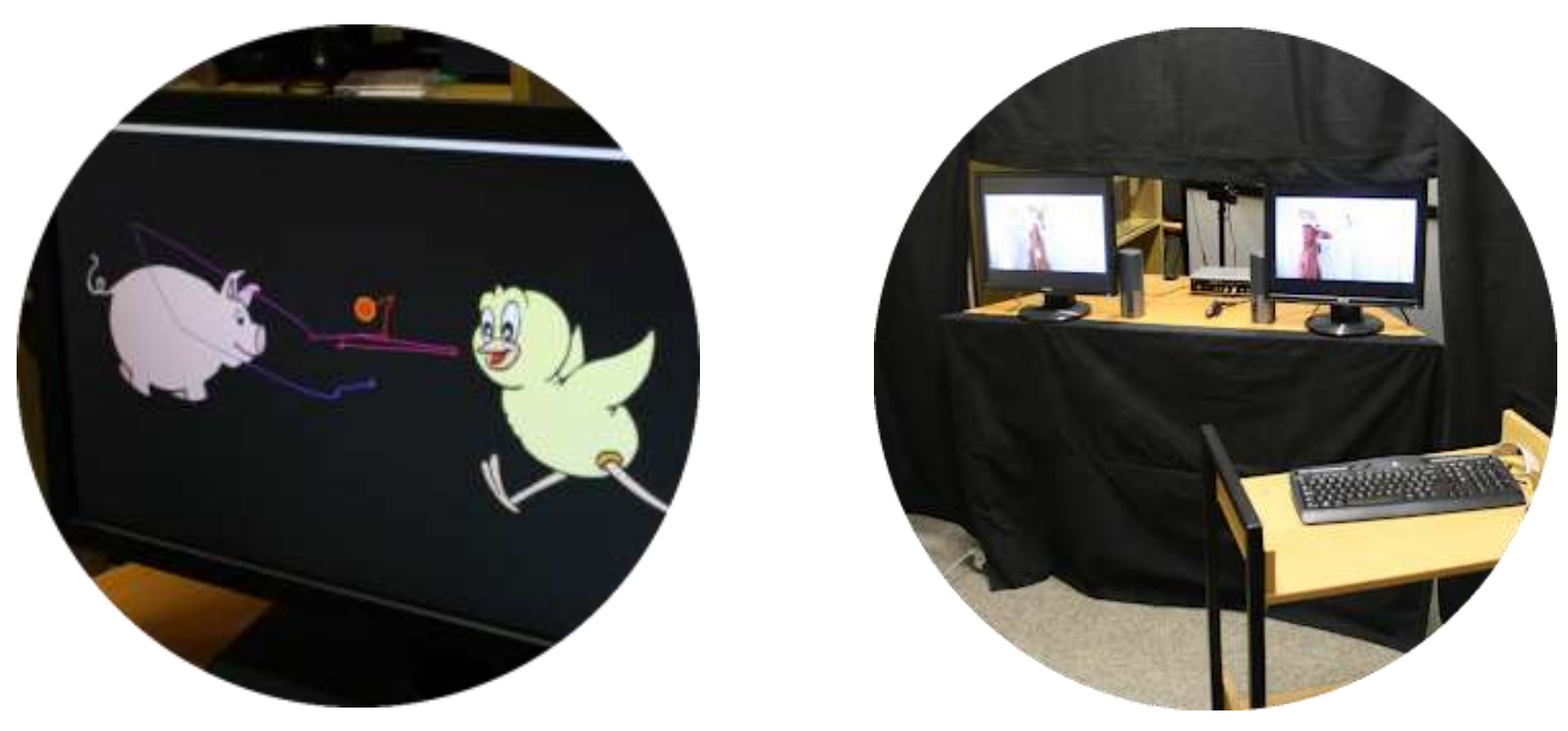

Obr. 2 a 3: Snímky z experimentálních úloh.

Přehled posledních studií je k nahlédnutí na stránce laboratoře https://labels.ff.cuni.cz/ .

Pokud vás naše témata zaujala, přihlaste se jako pokusná osoba https://experimenty-labels.cz/ nebo se ozvěte ohledně možnosti realizace výzkumu nebo odborné stáže.

Kontakt: labels@ff.cuni.cz

Děchtěrenko, F. (2021). LABELS: Laboratoř behaviorálních a lingvistických studií. E-psychologie, 15(4),102-103. https://doi.org/10.29364/epsy.430 